INDEPENDENT JOURNAL OF MANAGEMENT \& PRODUCTION (IJM\&P)

\title{
BUSINESS PROCESS RE-ENGINEERING: A PANACEA FOR REDUCING OPERATIONAL COST IN SERVICE ORGANIZATIONS
}

\author{
Joseph Sungau \\ Mzumbe University, Tanzania, United Republic Of \\ E-mail: sungaujj@gmail.com; jsungau@mzumbe.ac.tz
}

Philibert C. Ndunguru Mzumbe University, Tanzania, United Republic Of

E-mail: ndungurupc@yahoo.com

Submission: 19/06/2014

Accept: 03/07/2014

\section{ABSTRACT}

Organizations in today's business environment struggle on how to reduce operation cost for generating reasonable profit. In order to reduce Operational Cost, service organizations have been working hard to identify techniques that facilitate business processes improvement. In so doing, the global literature indicates that service organizations adopt BPR technique as a panacea of reducing Operational Cost. Despite a documented potentiality of BPR technique, a mixed empirical results, findings and conclusions regarding the effect of BPR on Operational Cost have been reported. Therefore, this paper aimed at assessing and explaining effects of BPR on Operational Cost. The study used cross-sectional survey design to investigate the effect of BPR on Operational Cost. Intensive literature review enabled the construction of structural measurement model, formulation of testable hypotheses and operationalization of constructs. In order to test the model and hypotheses, data were collected from ninety five (95) service organizations in Tanzania. Results of the study reveal that BPR and delivering speed have no direct effects on Operational Cost; they indirectly affect Operational Cost through the mediations of service quality. Therefore, BPR influences first both service quality and delivery speed in affecting Operational Cost of service organizations. It is now recommended that service organizations should use BPR as panacea of reducing Operational Cost. 
INDEPENDENT JOURNAL OF MANAGEMENT \& PRODUCTION (IJM\&P)

http://www.ijmp.jor.br

v. 6, n. 1, January - March 2015

ISSN: 2236-269X

DOI: 10.14807/ijmp.v6i1.248

Keywords: Business Process Re-engineering, Operational Cost, Service Organizations

\section{INTRODUCTION}

In today's business environment, customers expect to receive services that satisfy them regardless of the price they are willing to pay (AGI, 2001). In this regard, organizations have been working hard to reduce Operational Costs while offering what is required by customers. Organizations work hard to reduce Operational Costs which results in setting service prices which are afforded by majority of customers. The market rule is clear that unmet customer demands and/or expectations force customers to shift to other service providers (RUHL, 1997). Therefore, failure to meet customers demand and/or expectation is like giving a chance to a competitor. To avoid this, organizations have been working hard to improve their business processes in order to improve or maintain their services for retaining and/or attracting more customers (KOTLER, 2003).

Furthermore, in today's business environment, organizational effectiveness and efficiency have become watchwords in modern businesses. Organizations have been working hard in order to identify techniques that improve business processes for enhanced organizational performance while meeting customer demands and/or expectations (MOTHOBI, 2002; HEIZER; RENDER, 2011). As a result, several performance improvement techniques have been identified. The techniques include Six Sigma, Lean and Total Quality Management (TQM). The other techniques are Business Process Redesign, Business Process Improvement (BPI), Business Process Management (BPM) and BPR to mention the few (SLACK, et al, 2007; HEIZER; RENDER, 2011).

Amongst the performance improvement techniques, BPR is a radical technique proven to be the most effective means of enhancing organizational effectiveness and efficiency through improved business processes. The technique complements the division of labor theory through combining several tasks and using Information Technology (IT) (HAMMER; CHAMPY, 1993; BROERSMA, 1997; SUNGAU; MSANJILA, 2012). In that way, BPR reforms traditional business processes for reduced Operational Costs (CHENGHU, 2007). 
The adoption of BPR has resulted in several benefits (ADEYEMI; AREMU, 2008). The benefits include reduced Operating Costs, improved quality and service delivering speed (SLACK; CHAMBERS; JOHNSON, 2007). Other BPR benefits include improved productivity (MAUREEN; CHU; LIN; YU, 1995), dependability, flexibility (SLACK; CHAMBERS; JOHNSON, 2007) and finally it brings competitive advantage to an organization over others (MAUREEN, et al., 1995; MAGUTU, et al., 2010). In general, the BPR technique brings salvation to many organizations.

Despite the potentiality of the technique, many BPR projects have failed in some organizations. This is evidenced by studies by HAMMER and CHAMPY (1993), STREBEL (1996) and YAHYA (2002), which revealed that about $70 \%$ of BPR projects failed. The failure of BPR implementation was due to several factors that were faced by organizations. The factors include; lack of effective methodology, inappropriate process and unrealistic objectives. Other factors were over reliance on information technology (IT), lack of staff and top management support (YAHYA, 2002) and lack of common definition of BPR (CHEN, 2001). These challenges have been overcome by including BPR in strategic objectives of organizations.

Service organizations are more labor intensive than the manufacturing organizations (SLACK, et al, 2007; HEIZER; RENDER, 2011). This pressures them for effective business administration for better organizational performance and increased accountability. As a result, this forces service organizations to work hard to identify techniques to improve business processes for reduced Operational Costs. Based on global literature, BPR has been reported to be a technique that enables organizations to efficiently and effectively deliver service to customers (DEBELA; HAGOS, 2011; ADEYEMI; AREMU, 2008; YAHYA, 2002).

In service organizations, BPR is principally a transforming technique that enables service organizations to perfect business processes, operations and structures, but many unsuccessful BPR attempts have been due to the confusion surrounding BPR, and how it should be performed (KASSAHUN, 2012; WEERAKKODY, et al., 2011; COVERT, 1997). This has resulted in adopting BPR in a trial and error model, in other words, practical experience to improve business processes for reduced Operational Costs. However, despite its importance, BPR in service organizations have been relatively little researched (KASSAHUN, 2012; 
ADEYEMI; AREMU, 2008), this results in confusion of the BPR effect on Operational Costs. In this regard, the current paper determines the effect of BPR on Operational Costs.

\section{BUSINESS PROCESS RE-ENGINEERING}

Business process is a system that produces a given output or delivers a given service. It combines several processes. Several authors have defined the concept business process although the key concept of the definitions remains the same. The authors who defined business process includes DAVENPORT and SHORT (1990), DAVENPORT (1993), HAMMER and CHAMPY (1993), STODDARD and JARVENPEA (1995).

Based on their definitions, it can be deduced that business process has three aspects; system (set of interrelated activities), inputs (transforming and transformed resources) and desired outputs (good and/or services). The system is a set/package of logical arranged activities in such a way that it generates goods/delivers services after the transforming resources act on transformed resources (SLACK, et al, 2007).

A definition by STODDARD and JARVENPEA (1995), which is business process is a set of activities that transform a set of inputs into outputs (goods and services) for another person or process using people and equipment, is adopted in this study because the definition specifies types of input, process and what business process has to offer to both organizations and customers (output). Not only that, the definition categorizes the type of inputs and outputs to the system.

Engineering is a branch of science and technology which is concerned with the application of scientific, economic, social and practical knowledge in order to design, build, and maintain structures, machines, devices, systems and processes. In business processes, engineering is concerned with designing or structuring of business processes.

Re-engineering is restructuring of an organization or part of organization by removing non value adding processes or adding value adding processes through renovation, automation and networking. Re-engineering business process is restructuring part of organization. In re-engineering business process, an organization needs to identify business processes that are less effective in order to be perfected. 
According to CHEN (2001), there is no commonly agreed definition of BPR. Several authors have defined the term BPR in different ways. HAMMER and CHAMPY (1993), MANGANELLI and KLEIN (1994) and DAVENPORT and AREMU (1990) are among the authors who defined BPR. In this study, the definition of Hammer and Champy was adopted. The definition states that BPR is the fundamental rethinking and radical redesign of business processes to achieve dramatic improvements in critical contemporary measures of performance, such as cost, quality, service, and speed. From the definition of Hammer and Champy, the main concepts of BPR which can be deduced are fundamental rethinking, radical redesign, process and dramatic improvement. Not only that, the definition by Hammer and Champy is also regarded as a starting point of BPR (CHEN, 2001).

BPR focuses on the outcome of activities derived from the expectations and requirements of either internal or external customers. BPR aims at achieving dramatic reduction in cost, improvement in quality and reductions in cycle time (HAMMER; CHAMPY, 1993). The basic principle behind BPR is the notation of starting from the very beginning, where old practices are swept aside in favour of new creative and innovative processes (HE, 2005).

In contrast with other techniques, BPR is about dramatic improvement of business processes through fundamental rethinking how the organization's work should be done. This thinking distinguishes BPR from other business process improving techniques; which focus on functional or incremental improvement (HAMMER; CHAMPY, 1993).

Although BPR differs from other business process improving techniques but they share some common themes (BECKFORD, 1998). For instance, both they start with needs of customer and work backwards. The techniques that share some common themes with BPR include systems engineering, benchmarking and activity based costing ( $A B C)$. Other techniques includes scientific management, customer satisfaction measurement, cross functional team building, business process improvement (BPI) and total quality management (TQM) to mention few (BECKFORD, 1998).

Based on the shared themes, BPR is concerned with redesigning of business processes, eliminating non value adding activities, and application of information 
technology. Following the utilization of other techniques' concepts, BPR is known by many names, such as, core process redesign, new industrial engineering and working smarter (CHEN, 2001). All of them imply the same concept of integrating business process redesign and IT.

According to Hammer and Champy (1993), organizations re-engineer their business processes depending on different situations. These situations are categorized into three groups. Crisis management: The group involves organizations that are facing crisis; they have no choice rather than improving business processes. They re-engineer so that they move out of the crisis. Anticipatory management: The group involves organizations that foresee a crisis is approaching. These organizations re-engineer so that the coming crisis won't affect their business and Market leadership: The group involves organizations that want to continue to be market leaders. The re-engineering projects enable them to achieve their dreams by providing a better service than the current one.

\section{INFORMATION TECHNOLOGY IN BUSINESS PROCESS RE-ENGINEERING}

A key stimulus for BPR is the continuing development and deployment of sophisticated information system and networks. This can be evidenced by leading organizations which have been dominant in using technology to support innovative business processes, rather than refining old ways of doing work (DODARO; CROWLEY, 1997).

Following the use of new technology, Information Technology (IT) has been identified to be an enabler of BPR project in organizations (SUNGAU; MSANJILA, 2012). For instance, by implementing BPR, organizations explored opportunities provided by IT systems and tools to automate business activities for improved services to satisfy customers (LAUDON; LAUDON, 2006). Not only that, IT also provides potential roles by creating more flexible, team-oriented, coordinative and communication-based work capability in service organizations (WHITMAN, 1996).

HAMMER (1990) considers IT as the key factor in BPR for organization that wants to witness a "radical change" in its operations. Not only that, HAMMER (1990), AREMU and SAKA (2006) argued that IT is a strategic resource that facilitates major changes in competitive behaviours, marketing and customer service environment in achieving competitive advantages over others. Furthermore, DAVENPORT and 
SHORT (1990) posted that IT should be viewed as more than an automating or mechanizing force to fundamentally reshape the way business is done. It should be noted that IT and BPR have recursive relationship.

Meaning that IT capabilities should support the re-engineered business processes while BPR should provide a conductive environment for IT to work on. In this case, IT helps organizations to facilitate changes promoted by re-engineering for improved OP (SHIN; JEMELLA, 2002; DAVENPORT; SHORT, 1990; HAMMER, 1990). According to DAVENPORT and SHORT (1990), the roles of IT in BPR can be summarized in Table 1 below.

Table 1: The role of IT in BPR

\begin{tabular}{|l|l|}
\hline Role of IT & Organizational impact \\
\hline Transactional & $\begin{array}{l}\text { IT can transform unstructured business process } \\
\text { into standardized transactions }\end{array}$ \\
\hline Geographical & $\begin{array}{l}\text { IT can transfer information with rapidity and ease } \\
\text { across large distances, making business process } \\
\text { independent of locations }\end{array}$ \\
\hline Automation & $\begin{array}{l}\text { IT can reduce human labour in certain process by } \\
\text { replacing manual works }\end{array}$ \\
\hline Informational & $\begin{array}{l}\text { IT can bring vast volumes of detailed information } \\
\text { into a business process }\end{array}$ \\
\hline Analytical & $\begin{array}{l}\text { IT can bring complex analytical methods to bear } \\
\text { on a process }\end{array}$ \\
\hline Sequential & $\begin{array}{l}\text { IT enables changes in the sequence of tasks in } \\
\text { the process, often allowing multiple tasks to be } \\
\text { worked on simultaneously }\end{array}$ \\
\hline Knowledge management & $\begin{array}{l}\text { IT allows the capture and dissemination of } \\
\text { knowledge and expertise to improve the process }\end{array}$ \\
\hline Tracking & $\begin{array}{l}\text { IT allows detailed tracking of status, inputs and } \\
\text { outputs }\end{array}$ \\
\hline Reduction of intermediaries/networking & $\begin{array}{l}\text { IT can be used to connect two parties within a } \\
\text { process that would otherwise communicate } \\
\text { through intermediaries }\end{array}$ \\
\hline
\end{tabular}

Source: Davenport and Short (1990)

\section{ATTRIBUTES OF BUSINESS PROCESS RE-ENGINEERING}

From literature review, it has been identified that, BPR entails activities of business processes renovation, automation and networking in improving business processes. These attributes enable to study BPR scientifically. The attributes are presented here below:-

\subsection{Business process renovation}

Before automating the functional units, the elementary business processes are rearranged to form higher-level work process including technical linkages and interfaces of different systems. Business process renovation allows process 
redesign for the purpose of improving business operations. Renovating business process involves streamlining key business processes, making of succession or continuity of progression of work activities and sometimes combining other business processes (CONVERT, 1997; SHIN; JEMELLA, 2002; LAUDON; LAUDON, 2006; DEBELA, 2009).

In the renovation activity, several jobs need to be integrated and compressed into one so that a single worker at that work station need to assume full responsibility of all works (BROERSMA, 1997). BPR compresses processes horizontally as well as vertically. Furthermore, BPR empowers workers to make their own decisions with less interaction with their managers. This has benefits of fewer delays and lower overheads (BROERSMA, 1997).

The business process renovation sequences tasks to be done in a logical and natural precedence in which they can be performed. Through this arrangement, it allows several works to be done simultaneously. Furthermore, the sequencing of works in a logical and natural way leads to less rework of tasks, which has been a major source of delays in many organizations (BROERSMA, 1997).

In general, BPR through renovation involves eliminating business processes that have no values to organizations, instead increases Operational Costs. Not only that, renovation also targets on sequencing activities in a logical way in order to deliver a product or service to customers that has value (ATTARAN, 2003).

\subsection{Business process automation}

In the business process automation, BPR modify business processes by transforming business process from manual to automated one. The automation of business processes improves efficiency of an organization (SHIN; JEMELLA, 2002; DEBELA, 2009). The automation process is achieved through the application of IT. IT plays a major role in the BPR project as it facilitates the automation of various activities of organizations. For instance, IT allows organizational activities to be conducted at different locations to enable quicker delivery of services to customers. Also, IT facilitates quick search of customers' information or data (SHIN; JEMELLA, 2002). Not only that, IT facilitates rapid and paperless transactions.

In general automation allows an efficient and effective change the manner at which work is performed through standardization and centralization of business 
processes (ZYGIARIS, 2000). In the automation process, IT directly drives the process through workflows, paperless document management and online interaction. Automation does not only speeds up the business process and decreases cost, but also delivers a more secure and responsive service with an enhanced quality of process.

\subsection{Business process networking}

Business process networking is the linking activities/customers outside the section/organization to improve coordination by using IT in an organization (VENKATRAMAN, 1994; ATTARAN, 2004). According to ZYGIARIS (2000) in the 1990s when telecommunication technologies were becoming abundant and low costing, BPR was becoming a world-wide applicable managing technique for business upgrade. The networking of business processes enables employees to operate as a team using intranet/extranets.

Not only that, the networking also facilitates the workflow of activities and eliminating distances. Workers can work together even though they are located in different places. In this case, the application of IT eases commutation by networking workers/sections, facilitate accessibility of organizational information and linking managers/sections to different sections (AL-MASHARA; IRAN; ZAIRI, 2001; ATTARAN, 2004; HE, 2005; ADEYEMI; AREMU, 2008; DEBELE, 2009). Therefore, IT is an enabler of BPR and improves competitive position of an organization through networking organizational workers, sections or customers (CHEN, 2001; SUNGAU; MSANJILA, 2012).

Furthermore, according to DAVENPORT (1993), information and IT are rarely sufficient to bring about the process change; most process innovations are enabled by a combination of IT, information and organization/human resource changes. On the use of IT, HAMMER (1990) found that: IT could either 'pave the cowpath' of bureaucracy - unless the organization changed drastically, its IT would continuously reflect and reinforce bureaucratic and functional structures - or IT could help to create a learner, flatter and more responsive organization, a suggestion which is thus distinctly divergent from neo-classical economics, but only implicitly.

From this statement, it can be deduced that IT provides fast processing and response by automating business processes through networking (CHEN, 2001). IT 
capabilities facilitate the networking of workers and provide ease information access and coordination across organizational units. For instance, the internet can improve internal communication among different departments, work groups, branches and individuals. BPR facilitates also the external communication such as contact to customers, vendors, suppliers, government agencies and even competitors. BPR helps to overcome geographic barriers and thus enable broader acceptance of the process change. BPR alters the existing business process and brings cooperation between various departments using cross-functional teams instead of individuals working in isolated departments (ATTARAN, 2004).

\section{OPERATIONAL COST}

Operational Cost is expenditures which are under the direct control of the manager. The Operational Cost is made up of materials, labor and facilities. The items that contribute to Operational Cost are equipment, systems and communication costs. Operational Cost is measured using objective measures such as amount of money used/spent on each activity or subjective measure seeking opinions of the managers responsible. In lowering Operational Cost, organizations need to identify a unique way of delivering a service in order to gain a competitive advantage (COVERT, 1997).

Operational Cost is improved when day-to-day expenses incurred in running a business such as supplies, labour, inventory, facility and material costs are minimized (ARMISTEAD; BOWMAN; NEWTON, 1995; JONES; NOBLE; CROWE, 1997; ATTARAN; WOOD, 1999; GUNASEKARAN, et al., 2000; SLACK, et al, 2007; HESSON, 2007). For instance, service organizations have to make sure that ordering costs are minimized as possible. The minimization of costs can be achieved by minimizing the trips to the suppliers for ordering materials. This can be minimized by networking the supplier and the service organization in their relation. In this case, the transfer of order will be through emails, fax, telecommunication and other software that facilitates the linking between the supplier and service organization. By so doing, it minimizes operation cost to an organization.

Furthermore, service organizations have to reduce labor cost through minimization of number of employees involved in the business processes. The minimization of number of employee is done by reducing the non-value-adding 
processes, removing redundant work stations and automating business process. This enables the service organizations to reduce input to the system while increasing the number of customers served (CHAN; PEEL, 1998; GUNASEKARAN, et al, 2000; HESSON, 2007).

\section{BUSINESS PROCESS RE-ENGINEERING AND OPERATIONAL COST: CONCEPTUAL FRAMEWORK}

In reducing Operational Cost and improving delivering speed, BPR supports the linking of customers with service organizations through improved business processes. To ensure a good linkage, BPR improves business processes by adjusting, combining and networking business processes in service organizations which in turn improves productivity and service quality while lowers Operational Cost and operational cycle time (COVERT, 1997; ADEYEMI; AREMU, 2008; XIAOLI, 2011). By so doing, BPR brings customer satisfaction and strengthen the domestic and international market competition among service organizations.

According to literature view, the general assumption drawn is that Operational Cost decreases if the organization adopts a proper business process improving technique. In this regard, it is theorized that BPR, through the activities of renovation, automation and networking, affects service quality and delivering speed, which in turns reduces Operational Cost of a service organizations directly and indirectly. The relationship between constructs, are presented in Figure 1 below.

In summary, the research model presented in Figure 1 is hereby represented in system of null hypotheses and equations. It should be noted that since some criterions act as predictors of other criterions, SEM was used to analyze the collected data. 


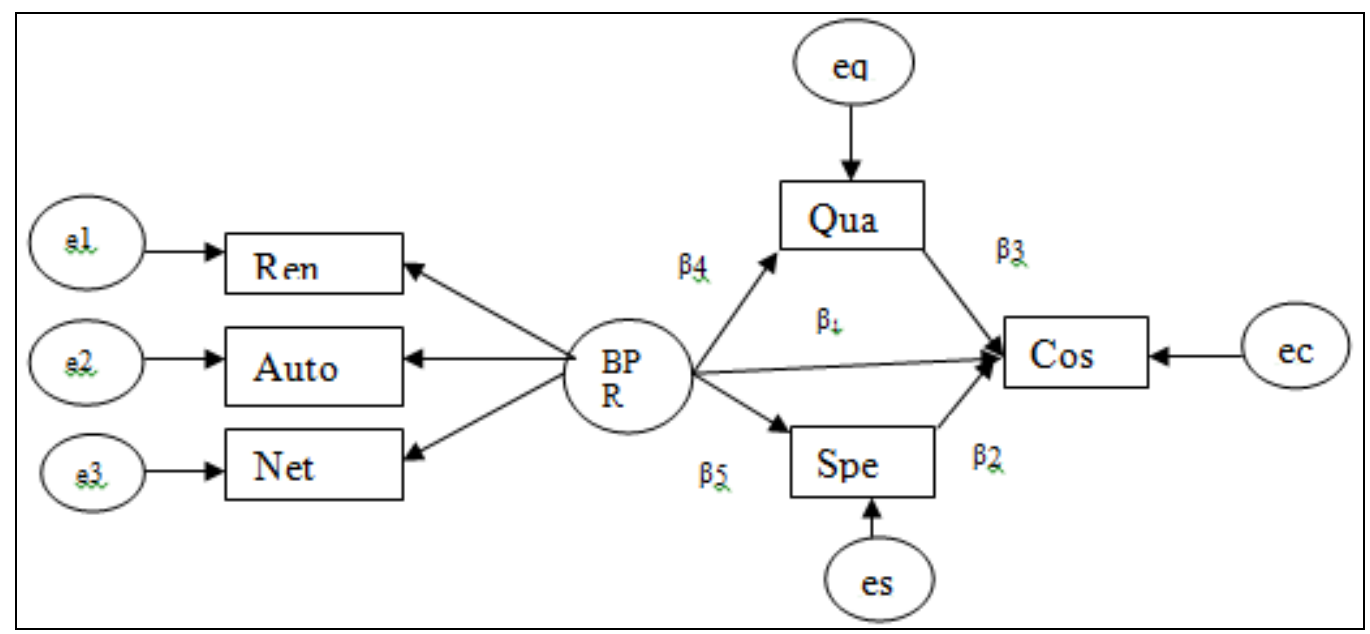

Figure 1: Conceptual framework

H01: BPR has no correlation with Operational Cost in service organizations.

H02: Service quality has no correlation with Operational Cost in service organizations.

H03: Delivering speed has no correlation with Operational Cost in service organizations.

$\operatorname{Cos}=\beta_{1} B P R+\beta_{3}$ spe $+\beta_{2}$ Qua + ec

Where $Q u a=$ service quality

Cos = operational $\cos t$

Spe $=$ delivering $\quad$ speed

$\operatorname{Re} n=$ renovation

Auto = automation

Net $=$ networking

$\beta_{i}=$ path coefficients and

ec $=$ unmeasured disturbances in endogeneous variable

\section{METHODOLOGY}

\subsection{Justification of paradigm and methodology}

This study has used a positivist paradigm in order to generate hypothesis that are empirically tested (NDUNGURU, 2007). The structural equation modelling of the surveyed data was formulated to study the interdependence of constructs. The constructs were studied by using multi - items scales which were total aggregated to observed and latent constructs (COFFMAN; MACCALLUM, 2005; VON DER HEIDT; SCOTT, 2007). 


\subsection{Type of Research Design}

Since the study aimed at determining the cause-effect relationship between exogenous construct and endogenous construct, the study design used in the study is a cross-sectional survey design. The design has been used because it enabled the researchers to collect data for the study from the sampled population at one point in time (BURNS; BUSH, 2002). Furthermore the design was selected because it enabled the researchers to collect large amount of data from a sizeable population in a highly economical way (HAIR et al., 2003).

\subsection{Constructs and Operationalization of Constructs}

Prior to designing the data collection questionnaire, the operationalization of research constructs was very important (NDUNGURU, 2007; HAIR et al., 2003). The operationalization was as presented in Table 3.

Table 3: Operationalization of constructs

\begin{tabular}{|c|c|}
\hline Construct & Operationalization \\
\hline $\begin{array}{l}\text { Renovation } \\
\text { (Ren) }\end{array}$ & $\begin{array}{l}\text { The construct was measured using the following items: - removing non-value adding } \\
\text { activities (MAGUTU; NYAMWANGE; KAPTOGE, 2010; AL-MASHARA; IRAN; ZAIRI, } \\
\text { 2001), replacing old machines, improvement of front and back offices, keep clear } \\
\text { gangways and allocation of offices in an organization }\end{array}$ \\
\hline $\begin{array}{l}\text { Automation } \\
\text { (Auto) }\end{array}$ & $\begin{array}{l}\text { The construct was measured using the following items: - level of use of IT, easy of } \\
\text { locating customers detail and IT infrastructures (HE, 2005) }\end{array}$ \\
\hline $\begin{array}{l}\text { Networking } \\
\text { (Net) }\end{array}$ & $\begin{array}{l}\text { The construct was measured using the following items: - easy of commutation (AL- } \\
\text { MASHARA; IRAN; ZAIRI, 2001; HE, 2005), accessibility of organizational information } \\
\text { and linking managers to different sections (HE, 2005) }\end{array}$ \\
\hline $\begin{array}{l}\text { Delivering } \\
\text { Speed (Spe) }\end{array}$ & $\begin{array}{l}\text { The construct was measured using the following items: - shortening of cycle time to } \\
\text { serve a customer, reduction of delays in serving customer, fastness of } \\
\text { communication, fastness in decision making and the period taken to deliver a service } \\
\text { since its request (AL-MASHARA; IRAN; ZAIRI, 2001) }\end{array}$ \\
\hline $\begin{array}{l}\text { Service } \\
\text { Quality }\end{array}$ & $\begin{array}{l}\text { The extent to which OP was improved by reducing damage frequency, data entry } \\
\text { error, documentation or invoicing error, error on credit claims and number of } \\
\text { customers returns. Service quality level was assessed by using } 5 \text { Likert scale } \\
\text { constructed statements that were aggregated to service quality construct. The five } \\
\text { statements are constructed based on:- ability to deliver a promised service in accurate } \\
\text { manner, willingness to help customers and provide prompt services, ability to inspire } \\
\text { trust and confidence, improvement in physical elements of service such as facilities } \\
\text { and equipment and treating customers as individuals (PARASURAMAN; ZEITHAML; } \\
\text { BERRY, 1988; AL-MASHARA; IRAN; ZAIRI, 2001) }\end{array}$ \\
\hline $\begin{array}{l}\text { Operational } \\
\text { Cost }\end{array}$ & $\begin{array}{l}\text { The extent to which OP was improved by reducing Operational Cost such as supplies } \\
\text { costs, overhead costs, labor costs, inventory costs, facility costs and material costs. } \\
\text { Operational Cost level was assessed by using } 5 \text { Likert scale constructed statements } \\
\text { that were aggregated to Operational Cost construct. The five statements are } \\
\text { constructed based on:- reduction in number of employees, reduction in unit cost, } \\
\text { reduction in paper works and reduction of rework cost (AL-MASHARA; IRAN; ZAIRI, } \\
\text { 2001; HE, 2005; KIM; MAHONEY, 2008) }\end{array}$ \\
\hline
\end{tabular}




\subsection{Study Area and Population}

The study area was Dar es Salaam city - Tanzania. The Dar es Salaam city was been selected because it is a major commercial city of Tanzania with majority of service organizations.

The study population comprised of all service organizations in Tanzania. The study included all service organizations which have been in operations for more than two years because assessing Operational Cost for organizations with less than two years of operations is illogical (OSTGAARD; BIRLEY, 1996). However, from the collected data, it was identified that eight service organizations were established after the year 2009. These service organizations were retained for further analyses in order to meet the minimum sample size requirement for the study depending on the number of parameters under the study (KLINE, 2005).

The target population for the study was made up of banking, public utility and pension fund sectors. Other sectors are insurance, health services, airline and communication. The selected sectors were thought to be knowledgeable with the elements of BPR. The units of inquiry of the proposed study are service organizations, however, managers of the service organizations were asked to respond to the questionnaire for the service organizations.

\subsection{Sample size, Sampling method and Data Collection}

A rule of thumb dictates that if proportion of target population having characteristics of interest is $p=0.5$ the samples size of $n=\frac{1}{e^{2}}$ is considered adequate provided that $e$ is the tolerated risk for estimating the proportion (NDUNGURU, 2007). In this study a $10 \%$ risk was considered acceptable and thus the 100 service organization constituted the sample size. Empirically, similar studies used sample size of 80 (ADEYEMI; AREMU, 2008), 110 (HE, 2005), 39 (MAGUTU, et al., 2008) and 70 (ALTINKEMER, 1998), to mention few.

Given the absence of a comprehensive sampling frame of service organizations in Tanzania, quota sampling method was used to select organizations. This non-probability method is a variant of stratified sampling that is recommended in scientific studies in the absence of comprehensive sampling frame (NDUNGURU, 2007). From the purposively selected sectors, specified proportions of service 
organizations were purposively identified and selected from a list of organizations obtained from National Bureau of Statistics (NBS) (SAUNDERS et al, 2005). In total, 95 service organizations responded to the questionnaires; being thirty (30) banking, three (3) public utility, three (3) pension fund, eighteen (18) insurance, twenty eight (28) health, seven (7) airline and six (6) telecommunication organizations.

Data were collected by using questionnaires (5-point Likert scale) with items for each construct. The questionnaire collected categorical data which during data analysis were assumed to be interval scale data (PERRY, 1998). Section managers were given questionnaires and they were asked to fill in.

\subsection{Data analysis}

The data analysis included preliminary, descriptive and inferential. Preliminary analysis was confined to response coding, data cleaning and screening, and normality testing. In addition, reliability and validity testing and factor analysis were also undertaken. Factor loadings of at least 0.30 were considered for total aggregation (COFFMAN; MACCALLUM, 2005; PALLANT, 2007; SAUNDERS, et al., 2005). In addition, univariate and multivariate outlier analysis was undertaken by assessing Z-score and Mahalanobis distance.

Descriptive analysis was confined to computing basic statistics and frequency distributions. Both measurement model and factor analyses were done, in the measurement model analysis; items that factor loaded below 0.3 were eliminated and that which loaded above 0.3 were factor analyzed to identify which items were factored out as one construct (COFFMAN; MACCALLUM, 2005). In this study items in each construct, were grouped as one component. Therefore, they were total aggregated to respective constructs (PALLANT, 2007).

Inferential analysis assessed the cause-effect relationship between constructs; testing of the association, ascertaining direct effect and model fit and testing of hypotheses (SAUNDERS, et al., 2005; KLINE, 2005).

\section{RESULTS AND FINDINGS}

\subsection{Preliminary Results}

From the results, all $z$ - score ranged between -2.77494 and 2.20715 indicating that there was no univariate outlier in all constructs of the study as Z-score 
are within recommended values; between \pm 3 (KLINE, 2005). For the case of multivariate outlier, assessment was done using Mahalanobis distance. The assessment was done as outliers may be resulted after a combination of several constructs (KLINE, 2005). The entered data were found to have no multivariate outlier as $p$ values were less than 0.001 .

Furthermore, the assessment of normality indicated that, data were univariate normally distributed as all skewness indices were less than 3.0 and the kurtosis indices were less than 10.0 (KLINE, 2005). In assessing multivariate analysis, the Kortosis critical ratio (c.r) values was 1.523 , which is less than 1.96 , indicating the presence multivariate normal distribution of data. Therefore, the subsequent analyses (mainly hypothesis testing) was done by using parametric formulas, such as Maximum Likelihood (ML) estimations as used in SEM (TABACHNICK; FIDELL, 2001).

\subsection{Respondents Profile}

Table 4 presents the frequency distribution and percentage regarding sectors, working section of respondent and BPR experience of organizations studied.

Over representation of banking (31.6\%), health $(29.5 \%)$ and insurance (18.9\%) sectors does not mean that in Tanzania there are more banks, health service and insurance organizations. The over representation followed purposive selection of organizations. More of these organizations are involved due to the evidence from literature review that more of them have adopted the BPR technique (TERZIOVSKI, et al., 2002; SHIN, 2002; HE, 2005; ADEYEMI; AREMU, 2008; MINYAN; TONGJAN, 2009; XIAOLI, 2011).

In this study majority of responds belong in operations (28.4\%) and human resource $(38.9 \%)$ sections. More are from these two sections because in most organizations, operations sections are ones knowledgeable about business processes. In the other hand, more human resource managers responded in this study because it is the section which is responsible for providing organizational information to external people.

Regarding experience, BPR practice is not a new feature in the management of service organizations in Tanzania. This is evidenced by findings of the study that 
majority (67.4\%) of service organizations have adopted BPR technique for over seven (7) years.

Table 4: Respondent Profile

\begin{tabular}{|c|c|c|c|}
\hline Item & Categories & $\begin{array}{l}\text { Number } \\
\text { Respondents }\end{array}$ & Percentage \\
\hline \multirow[t]{8}{*}{ Sector of the organization } & Banking & 30 & 31.6 \\
\hline & Health & 28 & 29.5 \\
\hline & Insurance & 18 & 18.9 \\
\hline & Public utility & 3 & 3.2 \\
\hline & Communication & 6 & 6.3 \\
\hline & Pension fund & 3 & 3.2 \\
\hline & Airline & 7 & 7.4 \\
\hline & Total & 95 & 100 \\
\hline \multirow{7}{*}{$\begin{array}{l}\text { Working section of the } \\
\text { respondent }\end{array}$} & Operations & 27 & 28.4 \\
\hline & Finance & 13 & 13.7 \\
\hline & Marketing & 9 & 9.5 \\
\hline & Quality & 1 & 1.1 \\
\hline & Human resource & 37 & 38.9 \\
\hline & General manager & 8 & 8.4 \\
\hline & Total & 95 & 100 \\
\hline \multirow[t]{5}{*}{ Experience in practising BPR } & Less 2 years & 8 & 8.4 \\
\hline & Between 2 and 6 years & 23 & 24.2 \\
\hline & Between 7 and 10 years & 28 & 29.5 \\
\hline & More than 10 years & 36 & 37.9 \\
\hline & Total & 95 & 100 \\
\hline
\end{tabular}

\subsection{Structural regression analysis}

The structural model was used to represent the causal hypothesis of the study (KLINE, 1998). The results were presented in two parts; structural models and its AMOS results and model fit summary. The model was hypothesized to assess the relationship among BPR, service quality, delivering speed and Operational Cost.

The objective of the paper is to determine the effect of BPR on Operational Cost of service industry. This objective was hypothesized by three hypotheses as presented in the conceptual framework. The conceptual hypotheses were later translated into statistical hypotheses for statistical testing. Figure 2 below presents the structural model to be assessed. 


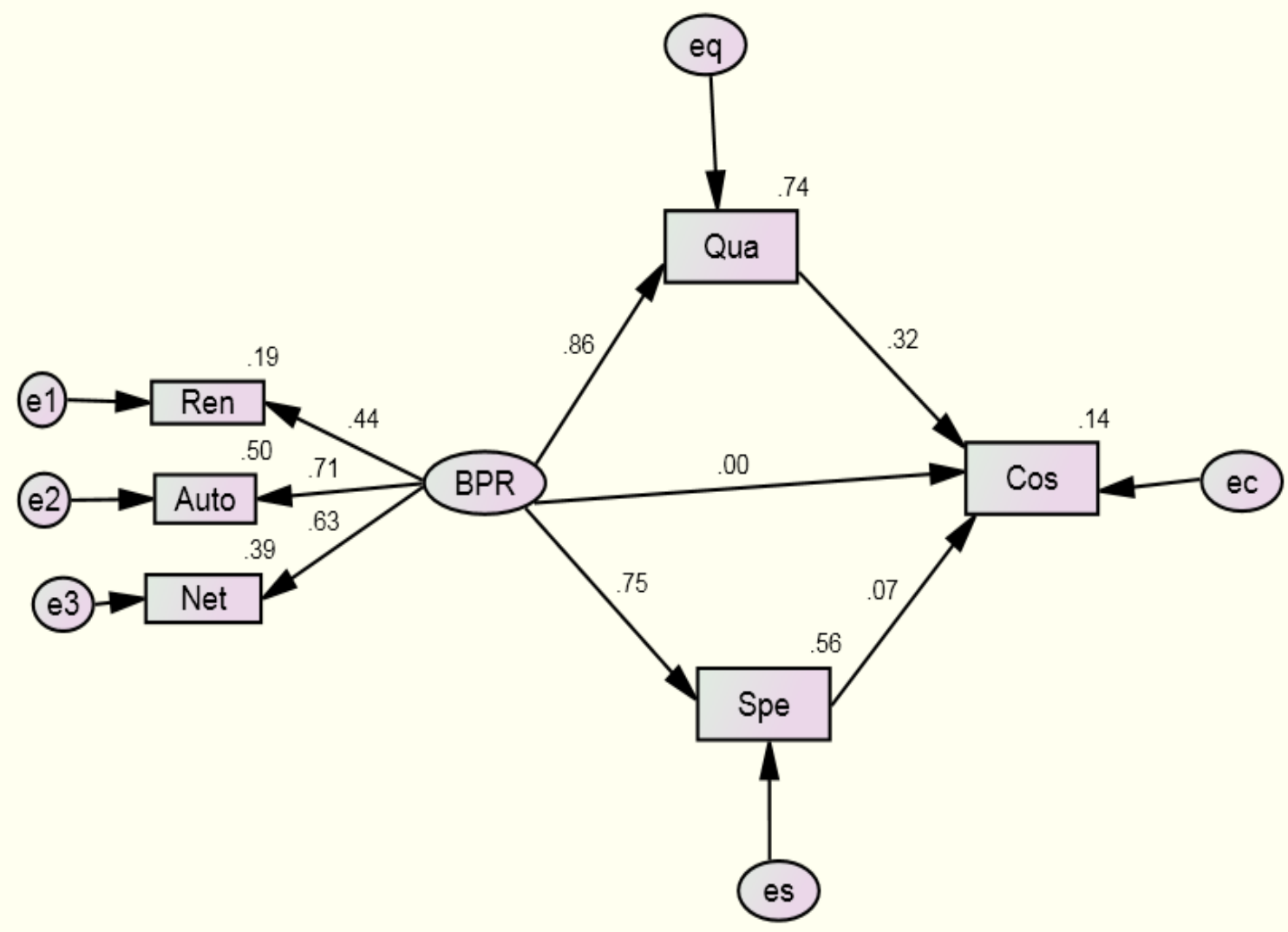

Figure 2: Model-Relationship among BPR, service quality, delivering speed and Operational Cost

From the Figure 2 above, the factor loadings for renovation (Ren), automation (Auto) and networking (Net) constructs are above 0.3. This indicates that the items are good measures of BPR construct. Furthermore, from Figure 2 it was deduced that BPR has no direct effect on Operational Cost (as 1 standard deviation of BPR causes 0.00 standard deviation to Operational Cost). However, in studying Figure 2, it was observed that BPR has indirect effects to Operational Cost. In the indirect effect, BPR improves service quality which in turn lowers Operational Cost (such that, 1 standard deviation of BPR improves 0.86 standard deviation of service quality; in turn 1 standard deviation of service quality lowers Operational Cost by 0.32 standard deviation).

Furthermore, indirectly BPR lowers Operational Cost through the improvement of delivering speed ( 1 standard deviation of BPR improves delivering speed by 0.75 standard deviation, which in turn 1 standard deviation of delivering speed lowers operation costs by 0.07 standard deviation). In comparison, indirect effect of BPR to Operational Cost via service quality is higher than that via delivering speed. Since the analysis used only standardized parameters, the effects of error terms to 
DOI: 10.14807/ijmp.v6i1.248

endogenous constructs are insignificant. The parameters that appear just above the observed constructs show how data deviate from the mean in each observed variable.

\subsection{Indirect effects in the relationship between BPR and Operational Cost}

Figure 2 above, show that there are indirect relationships between BPR and operation cost via service quality and delivering speed. The results of indirect relationships are presented in Table 5 below.

Table 5: Indirect effect between BPR and Operational Cost
\begin{tabular}{|l|l|l|}
\hline S/N & Constructs under assessment & Indirect effect \\
\hline 1 & BPR and Cos & 0.331 \\
2 & Qua and Cos & 0.000 \\
3 & Spe and Cos & 0.000 \\
\hline
\end{tabular}

From the results presented in Table 5 above, it was revealed that there was indirect relationship between BPR and Operational Cost as it was noted in Figure 2 above. Service quality and delivering speed had no indirect relationship to Operational Cost as indicated in the Table 5 above. In this case, there was a need to consider a reduced model of model to reflect the identified relationships as presented in the Figure 3 below in order to consider and test the significance of the indirect relationship between BPR and Operational Cost.

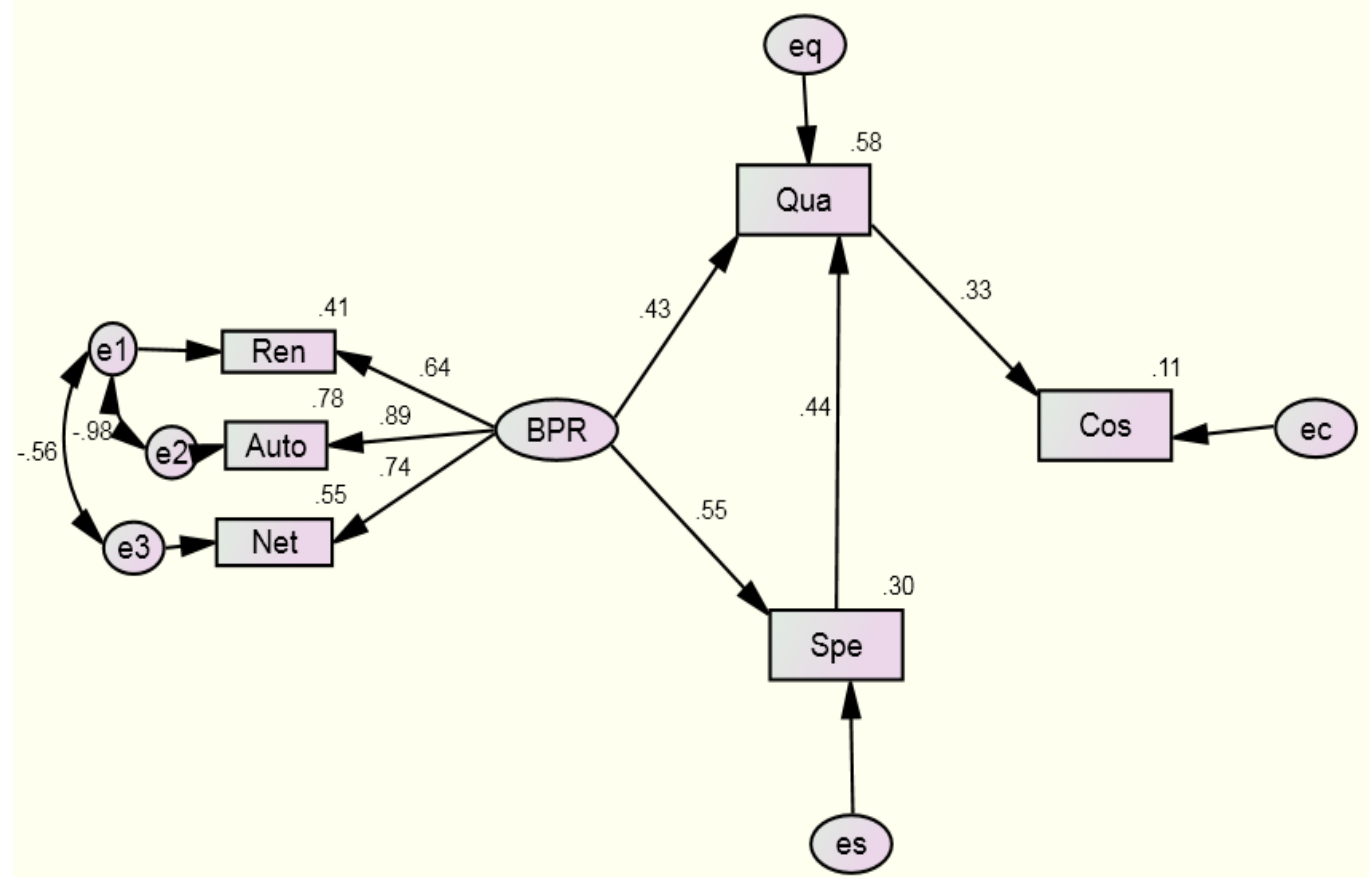

Figure 3: The reduced model of model-Relationship among BPR service quality, delivering speed and Operational Cost 
From the Figure 3 above, the factor loadings for renovation (Ren), automation (Auto) and networking (Net) constructs are above 0.3. This indicates that the items are good measures of BPR construct. Furthermore, from Figure 3 it was deduced that BPR has indirect effect on Operational Cost. In the indirect effect, BPR improves service quality which in turn lowers Operational Cost (such as 1 standard deviation of BPR improves 0.43 standard deviation of service quality; in turn 1 standard deviation of service quality lowers 0.33 standard deviation of operation costs).

Furthermore, indirectly BPR lowers Operational Cost through the improvement of delivering speed ( 1 standard deviation of BPR improves delivering speed by 0.55 standard deviation, which in turn 1 standard deviation of delivering speed improves service quality by 0.44 standard deviation and finally 1 standard deviation of service quality lowers operation costs by 0.33 standard deviation). Since the analysis uses only standardized parameters, the effects of error terms to endogenous constructs are insignificant. The parameters that appear just above the observed constructs show how data deviate from the mean in each observed construct.

\subsection{Mediation effect test in the relationship between BPR and Operational Cost}

The significance test in assessing results of indirect effects between BPR and Operational Cost via service quality and delivering speed are presented in Figure 2. Table 6, presents the results of SOBEL test for assessing the significance of mediation effect between BPR and Operational Cost.

Table 6: SOBEL test for indirect effects between BPR and Operational Cost

\begin{tabular}{|l|l|l|l|}
\hline & & P value & \\
\cline { 3 - 4 } Constructs under mediation & SOBEL test Statistic & One tailed & Two-tailed \\
\hline BPR $\rightarrow$ Qua $\rightarrow$ Cos & 2.581 & 0.005 & 0.010 \\
BPR $\rightarrow$ Spe $\rightarrow$ Qua & 3.534 & 0.0002 & 0.0004 \\
\hline
\end{tabular}

From Table 6 above, it was revealed that there is significant $(p<0.05$ ) mediation effects in the relationship between BPR and Operational Cost. Therefore, service quality and delivering speed are mediators of the relationship between BPR and Operational Cost. 


\subsection{Structural model goodness of fit for BPR and Operational Cost}

The goodness of fit for structural model that presents the relationship between BPR and Operational Cost was assessed using several indices. The results of goodness of fit are presented in Table 7 below.

Table 7: Goodness of fit of the reduced model of model

\begin{tabular}{|l|l|l|l|l|l|l|l|l|}
\hline Model & GFI & AGFI & NFI & RFI & IFI & TLI & CFI & RMSEA \\
\hline Default model & 0.963 & 0.869 & 0.943 & .858 & .973 & .929 & .972 & .096 \\
\hline Saturated model & 1.000 & & 1.000 & & 1.000 & & 1.000 & \\
\hline Independence model & 0.531 & 0.344 & 0.000 & .000 & .000 & .000 & .000 & .359 \\
\hline
\end{tabular} $\begin{aligned} & \text { Recommended values: AGFI, NFI, RFI, IFI, TLI and CFI should be close to } 1 \text { and } 0 \leq \text { RMSEA } \leq 0.1 \\
& \text { (HOOPER; COOUGHLAN; NULLEN, 2008; KLINE, 2005) }\end{aligned}$

From Table 7 above, it was revealed that the goodness of fit of the model is very good. The model fit is very good because all the indexes are close to 1 and that of the RMSEA fall in the recommended range (HOOPER; COOUGHLAN; NULLEN, 2008; KLINE, 2005). Therefore, results indicate that there were insignificant errors in measuring the endogenous constructs of model.

\subsection{Regression analysis for reduced model of model}

A further analysis was done to assess the direction, regression weights and the significance of the relationships between the predictors and the criterions of reduced model of model. The assessment was based on regression weights and $p$ values among constructs. The results of the analysis are presented in Table 8 below.

Table 8: Regression weights of the reduced model of model

\begin{tabular}{|l|l|l|l|l|l|}
\hline S/N & $\begin{array}{l}\text { Regressed } \\
\text { constructs }\end{array}$ & $\begin{array}{l}\text { Unstandardized } \\
\text { Regression weight }\end{array}$ & S.E & P value & $\begin{array}{l}\text { Standardized } \\
\text { regression weight }\end{array}$ \\
\hline 1 & Spe<---BPR & 0.434 & 0.085 & $<0.001$ & 0.546 \\
2 & Qua<----BPR & 0.292 & 0.071 & $<0.001$ & 0.425 \\
3 & Qua<---Spe & 0.382 & 0.078 & $<0.001$ & 0.443 \\
4 & Cos<--- Qua & 0.242 & 0.073 & $<0.001$ & 0.325 \\
\hline
\end{tabular}

From the results presented in Table 8, the regression weights are positive and significant $(p<0.05)$. Therefore, BPR positively and significantly lowers Operational Cost. The approximate mathematical relationship between constructs is presented in equation 1 below.

$\widehat{\operatorname{CoS}}=0.331 B P R+0.325 Q u a$ 


\section{Discussion of findings and Conclusion}

\subsection{Discussion of findings}

In determining the relationship between BPR and Operational Cost in service industry, the findings revealed that BPR has no significant direct effect on Operational Cost. However, BPR has indirect effects on Operational Cost. Furthermore, from the findings, it was identified that BPR indirectly improves service quality and delivering speed to improve Operational Cost. In this case, BPR improves first level constructs (service quality and delivering speed) which in turn affect the second level construct (Operational Cost).

Therefore, BPR, service quality and delivering speed are predictors of Operational Cost criterion. Service quality and delivering speed are criterions that act as predictors of the second level effect. These findings are somehow consistent with what was expected in this study because some of relationships were not significant.

Based on the research question that "what is the effect of BPR on Operational Cost of service industry?" the answer is that BPR lowers Operational Cost to service industry by $10.96 \%$. In lowering Operational Cost, BPR has significant indirect effect of 0.331 to Operational Cost in service organizations. These findings supports the findings by ZAHEER, MUSHTAQ AND ISHAQ (2008) which found that BPR reduces human, money and time costs by $69 \%, 81 \%$ and $74 \%$ respectively, YAHYA (2002) which found that BPR reduces overhead cost by $75 \%$ and HALL, ROSENTHAL and WADE (1993) which found that BPR reduces Operational Cost by $20 \%$.

Other studies which presented similar results are that of DEBELA (2009) which found that $75 \%$ reduction in manpower cost is due to adoption of BPR, and CHAMPY (1995) which found that BPR reduces Operational Cost by $40 \%$. There are some discrepancies between study findings with other reported studies. The discrepancies are due to the reason that the current study reports aggregated effect of BPR on operation cost construct while other studies presented effects of BPR on specific items of Operational Cost construct.

Not only that, some studies agreed that BPR reduces Operational Cost by either stating the percentage of respondent which agreed or not. For instant, the study by HE (2005) and CHAN and PEEL (1998) found that $86 \%$ and $60 \%$ of respondents found that BPR reduces Operational Cost respectively, while the studies 
by TENNANT and WU (2005), ATTARAN (2004), SHIN and JEMELLA (2002), KNIGHTS and WILMOTT (2000), RANGANATHAN and DHALIWAL (2001), HESSON, AL-AMEED, and SAMAKA (2007) and RINGIM, RAZALLI and HASNAN (2012) found that BPR reduces Operational Cost without stating the percentage of effect or by what percentage of respondents agreed or disagreed on the effect of BPR on Operational Cost.

From the items of the Operational Cost construct, it was identified that in reducing Operational Cost, more specifically, BPR enables service organizations to reduce paper works, decrease rework costs, decrease unit cost and decreases number of employees in business processes. Therefore, BPR lowers the inputs to an organization. The findings support the findings of SELLADURAI (2002) and RINGIM RAZALLI and HASNAN (2012). In general, the effect of BPR on Operational Cost was presented by equation 1 .

Based on literature review, it was hypothesized that H1: BPR has correlation with Operational Cost in service organizations; H2: Service quality has correlation with Operational Cost in service organizations and H3: Delivering speed has correlation with Operational Cost in service organizations. In the discussion of the hypotheses of the study, it should be noted that the hypotheses did not account the mediation effects; instead it examined bivariate interactions of constructs. Some of these results did not support the hypothesized relationships. However, when the indirect effect was considered, the implied relationships in specific objectives and questions were supported.

From the findings, in assessing $\mathrm{H} 1$ it was revealed that BPR had no significant correlation with Operational Cost in service organizations $(\beta 1=0 ; p>0.05)$. This was due to the reason that BPR had no direct effect on Operational Cost. In assessing $\mathrm{H} 2$, it was found that service quality has significant correlation with Operational Cost in service organizations $\left(\beta_{2} \neq 0 ; p<0.05\right)$. This was due to the fact that BPR has indirect effect on Operational Cost via service quality. Furthermore, in assessing $\mathrm{H} 3$, it was revealed that delivering speed has no correlation with Operational Cost $\left(\beta_{3}=0 ; p>0.05\right)$. This was due to the reason that delivering speed had no direct effect on Operational Cost.

\subsection{Conclusion}


From findings and discussion it is now concluded that BPR has no direct effect on Operational Cost; it indirectly affects Operational Cost. BPR improves both service quality and delivering speed which in turns affects Operational Cost in service organizations. Also, the effect of delivering speed to Operational Cost is mediated by service quality. In this case, service quality and delivering speed are mediators of BPR effects on Operational Cost. Therefore, BPR is a panacea of reducing Operational Cost. From this study, it is recommended that service organizations should adopt the BPR technique in order to improve business processes that will provide delighting services to customers at lower Operational Cost.

\section{REFERENCE}

ADEYEMI, S.; AREMU, M. A. (2008). Impact assessment of business Process reengineering on organizational performance. European Journal of Social Sciences, v. 7 , n. 1 , p. $115-125$.

AGI. (2001). The theory of constraints and its thinking processes. Jonal Program, New haven.

AL-MASHARA, M.; IRAN, Z.; ZAIRI, M. (2001). Business process re-engineering: A survey of international experience. Business Process Management Journal, v. 7 , n. 5 , p. 437-455.

AREMU, M. A.; SAKA, S. T. (2006). The impact of information technology on library, Management: A Marketing Perspective in Advances in Management. A Publication of Department of Business Administration, University of Ilorin, Nigeria, v. 5, n. 1, p. 141-150.

ARMISTEAD, C. G.; BOWMAN, C.; NEWTON, J. (1995). Managers' perceptions of the importance of supply, overhead and operating costs. International Journal of Operations \& Production Management, v. 15, n. 3, p. 16-28.

ATTARAN, M. (2004). Exploring the relationship between information technology and business process reengineering. Information \& Management, n. 41, p. 585-596.

ATTARAN, M. (2003). Information technology and business-process redesign. Business Process Management Journal, v. 9, n. 4, p. 440-458.

ATTARAN, M.; WOOD, G. G. (1999). How to succeed at reengineering. Management decision, v. 37, n. 10, p. 752-757.

BECKFORD, J. (1998). Quality, a critical introduction. London:Routledge.

BROERSMA, H. P. (1997). A theoretical approach to Business Process Reengineering. Thesis. Rand Afrikaans University, South Africa.

BURNS, A. C.; BUSH, R. F. (2002). Marketing research: Online research applications (4th Ed). New Jersey: Prentice Hall.

CHAMPY, J. (1995). Reengineering management. London: Harper Collins.

CHAN, P. S.; PEEL, D. (1998). Cause and impact of reengineering. Business Process Management Journal, v. 4, n. 1, p. 44-55. 
CHEN, Y. (2001). Empirical Modelling for Participative Business Process Reengineering. Thesis. University of Warwick.

CHENGHU, Z. (2007). The Bank IT outside wraps and its risk control. Journal of China Financial Computer, n. 4, p. 18 -24.

COFFMAN, D. L.; MACCALLUM, R. C. (2005). Using parcels to convert path analysis models into latent variable models. Multivariate Behavioral Research, $\mathrm{v}$. 40, n. 2, p. 235-259.

COVERT, M., (1997), Successfully Performing Business Process Reengineering, Visible Systems Corporation.

DAVENPORT, T.H. (1993). Process innovation. Boston: Harvard Business School Press.

DAVENPORT, T. H.; SHORT, J. E. (1990). The new industrial engineering: Information technology and business process redesign. Slogan Management Review, p. 11-27.

DEBELA, T. (2009). Business process reengineering in Ethiopian public organizations: The Relationship Between Theory and Practice, JBAS, v. 1, n. 2, p. 20-59.

DEBELA, T.; HAGOS, A. (2011). The design and implementation of business process reengineering in the Ethiopian public sector: $n$ assessment of four organizations. African Books Collective Limited.

DODARO, G. L.; CRWLEY, B. P. (1997). Business process reengineering assessment guide. United States General Accounting Office-Accounting and Information management Division, $3^{\text {rd }}$ Version.

GUNASEKARAN, A.; CHUNG, W. W. C.; KAN, K. (2000). Business process reengineering in British company: A case study. Ogistics Information Managenmen, v. 13, n. 5, p. 271-285.

HAIR, J. F.; BUSH, R. P.; ORTINAU, D. J. (2003). Marketing research: Within a changing information environment $\left(2^{\text {nd }} E d\right)$, New York: McGraw-Hill//rwin.

HALL, G.; ROSENTHAL, J.; WADE, J. (1993). How to make reengineering really work. Harvard Business Review, p. 119-131.

HAMMER, M., (1990). Reengineering Work: Don't Automate, Obliterate, Harvard Business Review, p. 104-11

HAMMER, M.; CHAMPY, J. (1993). Reengineering the Corporation: A Manifesto for Business Revolution. New York: Harper Business.

HE, X. J. (2005). A comparative study of Business Process Reengineering in China. Communication of the IIMA, v. 5, n. 2, p. 25-30.

HEIZER, J.; RENDER, B. (2011). Operations Management $\left(10^{\text {th }}\right.$ Ed). New Jersey: Prentice Hall.

HESSON, M. (2007). Business process reengineering in UAE public sector: A naturalization and residency case study. Business Process management Journal, v. 13 , n. 5 , p. $707-727$. 
HESSON, M.; AL-AMEED, H.; SAMAKA, M. (2007). Business process reengineering in UAE public sector: A town planning case study. Business Process Management Journal, v. 3, n. 3, p. 348-378.

HOOPER, D.; COUGHLAN, J.; NULLEN, M. R. (2008). Structural equation modelling: Guideline for determining model fit. Electronic Journal of Business Research Methods, v. 6, n. 1, p. 53-60.

JONES, T. M.; NOBLE, J. S.; CROWE, T. J. (1997). An Example of the Application of Production System Design Tools for the Implementation of Business Process Reengineering. International Journal Production Economics, n. 50, p. 69-78.

KASSAHUN, A. E. (2012). The effect of Business Process Reengineering on public sector organization performance (A developing economy context). PhD Thesis. RMIT University, Ethiopia.

KIM, S.; MAHONEY, J. (2008). Resource co-specialization, firm growth and organizational performance: an empirical analysis of organizational restructuring and its implementations. Working Paper.

KLINE, R. B. (2005). Principles and Practices of Structural Equation Modeling $\left(2^{\text {nd }} E d\right)$. New York: The Guilford Press.

KOTLER, P. (2003). Marketing Management $\left(11^{\text {th }} \mathrm{Ed}\right)$. Pearson Education Inc, Delhi.

KNIGHTS, D.; WILMOTT, H. (2000). The reengineering revolution? Critical studies of corporate change. London: Sage.

MAGUTU, P. O.; NYAMWANGE, S. O.; KAPTOGE, G. K. (2010). Business process reengineering for competitive advantage: Key factors that may lead to the success or failure of the BPR Implementation (The Wrigley Company), African Journal of Business \& Management, n. 1, p. 135-150

MANGANELLI, R. L.; KLEIN, M.M. (1994). The re-engineering Handbook: A stepby-step guide to business transformation. New York: American Management Association.

MINYAN, Y.; TONGJAN, Z. (2009). The empirical analysis on the structural model of business process reengineering of National Commercial Banks. Journal of Reformation and Strategy, n. 3, p. 69-72.

MOTHOBI, M. (2002). Business process re-engineering: Improving business operations. Dissertation. The University of Wales.

NDUNGURU, P. C. (2007). Lectures on research methods for social sciences. Research Information and Publications Department, Mzumbe University.

OSTGAARD, T. A.; BIRLEY, S. (1996). New venture growth and personal networks. Journal of Business Research, v. 36, n. 1, p. 37-50.

PALLANT, J. (2007). SPSS survival manual: A step-by-step guide to data analysis using SPSS version 15 ( $\left.3^{\text {rd }} \mathrm{Ed}\right)$. Singapore: Markono Print Media Pte Ltd.

PARASURAMAN, A.; ZEITHAML, V.; BERRY, L. (1988). SERQUAL: A multiple item scale for measuring consumer perception of service quality. J Retail, n. 64, p. 12-40

PERRY, C. (1998). A structural approach to presenting theses: Notes for students and their supervisors. Australian Marketing Journal, v. 6, n. 1, p. 63-68. 
RANGANATHAN, C.; DHALIWAL, J. S. (2001). A survey of business process reengineering practices in Singapore. Information \& Management, v. 39, n. 2, p. 125-134.

RINGIM, K. J.; RAZALLI, M. R. (2011). Effect of business process reengineering factors on organizational performance of Nigerian banks: Information technology capacity as the moderating factor. International Journal of Business and Social Science, v. 2, n. 13, p. 198-201.

RINGIM, K. J.; RAZALLI, M. R.; HASNAN, N. (2012). Moderating effect of information technology (IT) capability on the relationship between business process reengineering factors and organizational performance of Bank. African Journal of Business Management, v. 6, n. 16, p. 555-5567

RUHL, J. (1997). The Theory of Constraints within a Cost Management Framework. Journal of Cost Management, p. 16-24.

SAUNDERS, M.; LEWIS, P.; THORNHILL, A. (2005). Research methods for business studies. London: Pearson Profession Limited.

SHIN, N.; JEMELLA, D. (2002). Business process re-engineering and performance improvement: The Case of Chase Manhattan Bank. Business Process Management Journal, v. 8, n. 4, p. 351-363.

SLACK, N.; CHAMBERS, S.; JOHNSTON, R. (2007). Operation Management $\left(5^{\text {th }}\right.$ Ed). London: Prentice Hall.

SELLADURAI, R. (2002). An organizational profitability, productivity, performance (PPP) model: Going beyond TQM and BPR. The journal of total quality management, v. 13, n. 5, p. 613-619.

STODDARD D. B.; JARVENPEA S. L. (1995). Business process redesign tactics for managing radical change. Journal of Management Information System, v. 12, n. 1, p. 61-107.

STREBEL, P. (1996). Why do employees resist change? Harvard Business Review, n. 3, p. 86-92.

SUNGAU, J; MSANJILA, S. S. (2012). On IT enabling of business process reengineering in organizations. Advanced Materials research, n. 404-408, p. 51775181.

TABACHNICK, B. G.; FIDELL, L. S. (2001). Using multivariate statistics $\left(4^{\text {th }} \mathrm{Ed}\right)$. Boston: Allyn \& Bacon.

TENG, J. T.; KETTINGER, W, J. (1995). Business process redesign and information architecture: Exploring the relationship. ACM SIGMIS, v. 26, n. 1, p. 30-42.

TENNANT, C.; WU, Y. (2005). Research and concepts: The application of business process reengineering in the UK. The TQM Magazune, v. 17, n. 6, p. 537-545.

TERZIOVSKI, M.; TITZPATRICK, P.; O'NEIL, P. (2003). Successful predictors of business process reengineering (BPR) in fincial services. Int. J. Production Economics, n. 84, p. 35-50.

YAHYA, B. N. (2002). Business process re-engineering: concepts, causes and effects. Journal of Technical Industries, v. 4, n. 2, p. 102-110. 
VENKATRAMAN, N. (1994). IT enabled transformation: From automation to business scope redefinition. Sloan Management Review, v. 35, n. 2, p. 73-87.

VON DER HEIDT, T.; SCOTT, D. R. (2007). Partial aggregation for complex structural equation modeling (SEM) and small sample sizes: An illustration using a multi-stakeholder model of cooperative interorganisational relationships (IORs) in product innovation. 21st ANZAM Conference, Sydney. 4 - 7 December, 2007.

WEERAKKODY, V.; JANSSEN, M.; DWIVEDI, Y. K. (2011). Tranformational change and business process reengineering (BPR): Lesson from the British and Dutch public sector. Government Information Quarterly, n. 28, p. 320-328.

WHITMAN, M. E. (1996). IT divergence in reengineering support: Performance expectations vs perceptions. Information \& Management, v. 30, n. 5, p. 239-250.

XIAOLI, L. (2011). Correlation between business Process reengineering and operation performance of National Commercial Banks. Journal of Innovation and Management, n. 7, p. 981-985.

ZAHEER, A.; MUSHTAQ, K.; ISHAQ, H. M. (2008). Reengineering the procurement process in public sector organization: A case study. International Bulletin of Business Administration, 1451-143X (3). Retrieved on April 10 ${ }^{\text {th }}, 2012$ from the World Wide Web: http://www.eurojournals.com/IBBA_3_04.pdf.

ZYGIARIS, S. (2000). Business process reengineering BPR: Report produced for the EC funded project, INNOREGIO: dissemination of Innovation and knowledge management techniques, HELLAS SA. 